\title{
An Experimental Approach to Investigate the Transport of Ammonia as a Fuel Contaminant in Proton Exchange Membrane Fuel Cells
}

\author{
Ryan M. Jung, ${ }^{\mathrm{a},{ }^{*}}$ Hyun-Seok Cho, ${ }^{\mathrm{b}}$ Sehkyu Park, ${ }^{\mathrm{c}}$ and J. W. Van Zee ${ }^{\mathrm{b}}$ \\ ${ }^{a}$ Bioenvironmental Engineering, Robins Air Force Base, \\ Warner Robins, GA 31098, USA \\ ${ }^{b}$ Department of Chemical and Biological Engineering, University of Alabama \\ Tuscaloosa, AL 35487, USA \\ ${ }^{c}$ Department of Chemical Engineering, Kwangwoon University \\ Seoul, 139-701, S. Korea
}

\author{
Manuscript submitted to \\ Journal of Power Sources \\ Dr. Chris K. Dyer \\ Regional Editor for N. and S. America \\ Compact Power Inc., \\ 16 Seven Oaks Circle, Madison, NJ 07940-1314, USA
}

Submitted August 04, 2014

Revised manuscript submitted September 26, 2014

* Corresponding author: Phone: (478)-327-7555, e-mail: ryan.jung.1@us.af.mil, yaro96@gmail.com, fax: $1-478-327-7525$ 


\begin{abstract}
Data are presented for the transport of $\mathrm{NH}_{3}$ from the a node to the cathode for various inlet conditions in a $\mathrm{N}_{2} / \mathrm{N}_{2}$ laboratory-scale fuel cell at open circuit voltage (OCV). The data $\mathrm{w}$ ere obtained with a $\mathrm{m}$ aterial ba lance technique, $\mathrm{w}$ hich uses a $\mathrm{n}$ i on s elective electrode (ISE) to determine the concentration of ammonium ions. The results show that ammonia did not move across the membrane when the feed to both electrodes was dry. However, with humidified feeds on either side, the ammonia was transported from the anode to the cathode. The data include changes in the relative humidity of the anode inlet and the flowrate on the cathode. The data support a diffusion-solubility mechanism in a $\mathrm{N}_{2} / \mathrm{N}_{2}$ system at $\mathrm{OCV}$.
\end{abstract}

Keywords: PEMFCs; ammonia; fuel contaminant; transport, diffusion coefficient 


\section{Introduction}

The quality of $\mathrm{H}_{2}$ and the presence of contaminants like $\mathrm{CO}, \mathrm{NH}_{3}, \mathrm{H}_{2} \mathrm{~S}$ is a major concern for international standards for proton exchange membrane fuel cells (PEMFCs) used for transportation [1]. Several research groups have published papers showing the effects of $\mathrm{NH}_{3}$ on the performance of PEMFCs [2-10]. Uribe et al.[2], Soto et al.[3], and Halseid et al .[4] concluded that $\mathrm{p}$ erformance de gradation $\mathrm{r}$ esulted $\mathrm{f}$ rom $\mathrm{t}$ he 1 oss of conductivity in the anode cat alyst layer and the membrane in which a mmonium i ons displaced proton sites. They also observed that $\mathrm{NH}_{3}$ was not electrochemically active on the surface of a Pt catalyst by using cyclic voltammetry (CV) scans on both electrodes. They focused on the a node si de b ecause ammonia is a fuel contaminant. However, Halseid et al . [4-7] postulated that a mmonia c ould transfer $t o$ the $\mathrm{c}$ athode $\mathrm{s}$ ide and influence the oxygen reduction reaction ( ORR) by oxidizing ammonia a thi gher potentials than $0.7 \mathrm{~V}$. They postulated that the main reason for performance degradation in the fuel cell was likely due to the cathode, not the anode. Furthermore, they showed that $\mathrm{N}_{2}$ and $\mathrm{N} \mathrm{O}$ c ould be ge nerated through an $\mathrm{NH}_{3}$ oxidation $\mathrm{r}$ eaction by using differential el ectrochemical mass spe ctrometry [7]. Hongsirikarn e ta $1 . \quad[9,10]$ investigated the effect of $\mathrm{N} \mathrm{H}_{3}$ and $\mathrm{NH}_{4}{ }^{+}$in $\mathrm{t}$ he aqueous and va por pha ses on $\mathrm{t}$ he conductivity of a Nafion ${ }^{\circledR}$ membrane, and concluded that the ope ration of PEMFCs at relatively high humidity improves the a mmonia tolerance. Zhang et a l. [11] proposed $\mathrm{NH}_{3}$ or $\mathrm{NH}_{4}{ }^{+}$could reduce the active area of the catalyst by adsorbing onto Pt surface in contrast to the evidence in references [2] and [3].

Prior to these PEMFC studies, Cussler and co-workers [12-14] suggested three possible mechanisms for $\mathrm{N} \mathrm{H}_{3}$ transport in Nafion ${ }^{\circledR}$ : di ffusion-solubility, di ffusion- 
reaction, and mobile $\mathrm{c}$ arrier $\mathrm{f}$ acilitation. In $\mathrm{t}$ he diffusion-solubility mechanism, $\mathrm{t}$ he ammonia flux va ries linearly with the am monia partial pressure difference. With the diffusion-reaction mechanism, ammonia reacts with the membrane to produce regions of high salt concentration that later dissolve preferentially so that the ammonia flux depends on the first power of ammonia partial pressure at high pressures and the square of this pressure at 1 ow pressure $\mathrm{s}$. In the mobile carrier $\mathrm{m}$ echanism, the $\mathrm{m}$ embrane $\mathrm{r}$ eacts selectively with the solute to form a complex, which diffuses across the membrane and releases the am monia on the $\mathrm{p}$ ermeate si de. Upon $\mathrm{r}$ elease, the complex-free carrier diffuses back to the high partial pressure side of the membrane so that a plot of ammonia flux against ammonia pressure shows a concave or downward curvature. In an attempt to provide a basis for understanding the ways in which ammonia affects the performance of the fuel ce ll, we presen $t$ he re exp eriments to understand the transport of a mmonia in PEMFCs.

\section{Experimental}

\subsection{In-situ single cell for $\mathrm{NH}_{3}$ transport through MEA}

The MEA used in this study was the GORE ${ }^{\mathrm{TM}}$ PRIMEA $^{\circledR}$ Series 5621 and 5710. To reduce the expe rimental error for $\mathrm{m}$ ass ba lance expe riments, we chos e the higher capacity PRIMEA ${ }^{\circledR} 5621(\approx 2$ times acid capacity), and the thinner (less a cid c apacity) PRIMEA $^{\circledR} 5710$ to minimize the time to reach equilibrium for the diffusion experiments. The MEA had a nominal thickness of $35 \mu \mathrm{m}$ and a catalyst loading of $0.45 \mathrm{mgcm}^{-2} \mathrm{Pt}-\mathrm{Ru}$ alloy catalyst on $\mathrm{t}$ he a node a nd $0.6 \mathrm{mgcm}^{-2} \mathrm{Pt} / \mathrm{C}$ on $\mathrm{t}$ he $\mathrm{c}$ athode for $\mathrm{t}$ he $\mathrm{GORE}^{\mathrm{TM}}$ PRIMEA $^{\circledR}$ Series 5621 , and a catalyst loading of $0.1 \mathrm{mgcm}^{-2} \mathrm{Pt} / \mathrm{C}$ on the anode and 0.4 
$\mathrm{mgcm}^{-2} \mathrm{Pt} / \mathrm{C}$ on the cathode for the GORE ${ }^{\mathrm{TM}}$ PRIMEA $^{\circledR}$ Series $5710(25 \mu \mathrm{m})$. The gas diffusion layer (CARBEL ${ }^{\mathrm{TM}} \mathrm{CL}$ ) and silicon coated glass fiber gaskets were used on the anode and cathode sides. Eight lubricated bolts were threaded into tapped holes on one of the end plates, and the $\mathrm{c}$ ell $\mathrm{w}$ as compressed $\mathrm{w}$ ith a torque of $50 \mathrm{in} 1 \mathrm{bf} / \mathrm{bolt}$. The experiments were performed using a model 890CL load made by Scribner Associates, Inc. Mass flow controllers (MKS Instruments) w ere cal ibrated for ga sl ow with a bubble flow meter at room te mperature. The feed ga s t o the anode w as humidified by u sing bottles supplied by F uel Cell Technologies, Inc. These humidity bottles were calibrated with a VAISALA de w point meter to establish the set-point temperature for $\mathrm{RH}=50 \%$, $80 \%$ and $100 \%$ at a given flowrate. The tubing between the humidity bottles and the fuel cell $\mathrm{w}$ as he ated $10^{\circ} \mathrm{C}$ higher $\mathrm{t}$ han that of the humidity bottle to prevent $\mathrm{w}$ ater $\mathrm{v}$ apor condensation. A graphite triple-path serpentine flow field was used on e ach side of the MEA. The temperature of the cell was fixed at $70^{\circ} \mathrm{C}$ for the GORE ${ }^{\mathrm{TM}}$ PRIMEA $^{\circledR}$ Series 5621 , a nd at $80^{\circ} \mathrm{C}$ for the GORE $^{\mathrm{TM}}$ PRIMEA $^{\circledR}$ Series 5710 e xperiment. The back pressures were held at $101 \mathrm{kPa}$ on both sides.

An Ion Selective E lectrode ( ISE, Cole-Parmer ${ }^{\circledR}$ Combination I on-Selective Electrodes, $\mathrm{E} \mathrm{W}-27502-03) \mathrm{w}$ as e mployed $\mathrm{f}$ or $\mathrm{t}$ he $\mathrm{t}$ ransient $\mathrm{m}$ onitoring of $\mathrm{NH}_{4}{ }^{+}$ concentrations. The concentration of $\mathrm{NH}_{4}{ }^{+}$was converted from the potential measured by an Orion 4-stars meter (Thermo scientific Orion 4-star Plus pH/ISE meter, \#1215000) with a $0.1 \mathrm{mV} r$ esolution. The e lectrode slope $\mathrm{f}$ or $\mathrm{c}$ onversion $\mathrm{f}$ rom pot ential $\mathrm{t} \mathrm{o}$ concentration was cal ibrated with 1,10 , and 100pp m standard s olutions ( from Hach) before each experiment. The buffer solution for the Ionic Strength Adjustment (ISA) was prepared by mixing $0.25 \mathrm{M}$ magnesium acet ate and $0.5 \mathrm{M}$ acet ic aci $\mathrm{d}$. T he ISA 
maintained the $\mathrm{pH}$ of solution at approximately 4.7 during the experiments so that all of the $\mathrm{NH}_{3}$ was converted to $\mathrm{NH}_{4}{ }^{+}$for detection with the ammonium ISE. Initially, $100 \mathrm{~mL}$ of $1 \mathrm{ppm} \mathrm{NH} \mathrm{N}_{4} \mathrm{Cl}$ and $20 \mathrm{~mL}$ ISA were added to the flask and used for capturing $\mathrm{NH}_{3}$ and $\mathrm{NH}_{4}{ }^{+}$in the exit streams from the anode and cathode.

All experiments were performed at open circuit conditions (OCV); thus, our designation of anode and cathode refers to the sides of the MEA and the cell where the $\mathrm{NH}_{3}$ entered (anode) and the $\mathrm{NH}_{3}$ was transported (cathode). The MEA was exposed to $100 \mathrm{ppm} \mathrm{NH}_{3}$ in UHP $\mathrm{N}_{2}$ by dry injection on the anode with neat UHP $\mathrm{N}_{2}$ on the cathode. The flowrate was $150 \mathrm{sccm}^{\text {a }}$ for both the anode and cathode sides. At the start of some experiments and after assembling the MEA in the cell, the cell was purged with heated $\mathrm{N}_{2}$ for $20 \mathrm{~h}$ to dry the cell and MEA.

The material balance apparatus is illustrated in Fig. 1. The gases were bubbled into the flasks containing the IS A, and $\mathrm{NH}_{3}$ was coll ected from each side of the cell during the experiment. Each flask had three necks which contained the dispersion tube from the outlet of the fuel cell, the ISE, and a connection to a knock-out for collecting water condensation from the flask and subsequent venting. A magnetic stir bar was used in the flask and a fan beside the flask was us ed t o p revent a $\mathrm{n}$ increase of s olution temperature from the PEMFC gases. All experiments were carried out with a $\mathrm{N}_{2} / \mathrm{N}_{2} \mathrm{UHP}$ system feed.

The experiments to study the transport of $\mathrm{NH}_{3}$ were composed of four steps:

1) $\mathrm{N}$ eat, heated $\mathrm{N}_{2}$ flowed to bot h e lectrodes for 20 min to confirm no pot ential changes of the ISE without $\mathrm{NH}_{3}$.

\footnotetext{
${ }^{\mathrm{a}} \mathrm{sccm}=$ standard $\mathrm{cm}^{3} \mathrm{~min}^{-1}$.
} 
2) 100ppm dry $\mathrm{NH}_{3} / \mathrm{N}_{2}$ was injected to the anode with dry $\mathrm{N}_{2}$ being fed to the cathode until steady state was reached.

3) The anode gas was changed to a humid condition while keeping a dry cathode gas feed until steady state was attained. The humid condition on the anode was obtained by mixing humid $\mathrm{N}_{2}$ gas with a dry $\mathrm{NH}_{3} / \mathrm{N}_{2}$ mixture gas.

4) When the amount of $\mathrm{NH}_{3}$ exiting from both electrodes reached steady state in \#3, humidified gas was fed to the cathode.

The solution in flasks was changed and the ISE was calibrated between each step. Experiments were performed at two levels of Relative Humidity $(\mathrm{RH}=50 \%$ and $80 \%)$ and three concentrations of $\mathrm{NH}_{3}$ in the $\mathrm{N}_{2}(100,200$ and $300 \mathrm{ppm})$. The flux of $\mathrm{NH}_{3}$ to the cathode was calculated from the moles of ammonia collected using a value of $23 \mathrm{~cm}^{2}$ of active MEA area.

\subsection{Ex-situ diffusivity measured by $\mathrm{NH}_{3}$ mass uptake}

Membrane strips $(9 \mathrm{~cm} \times 4 \mathrm{~cm}$ of $\mathrm{N} 117$ for each sample) were partially (only $2.5 \mathrm{~cm}$ length) soaked in $500 \mathrm{ml}$ s olutions of mixed ratios of $1 \mathrm{M}$ a mmonium chloride $\left(\mathrm{NH}_{4} \mathrm{Cl}\right)$ and $1 \mathrm{M}$ hydrochloric acid (HCL), and stored at different temperatures (i.e., 23 and $70^{\circ} \mathrm{C}$ ). After be ing al lowed to re ach equilibrium be tween membrane s trips and solutions, the membrane strip was cut into 9 pieces $1 \mathrm{~cm}$ in length, and the amount of ammonium ions in each membrane was measured by titration method. More details of the mass uptake methods for self-diffusivity are introduced in reference [15]. The di ffusivity w as then obtained by fitting the experimental $\mathrm{c}$ urve (x-axis, di stance of membrane and $y$-axis, normalized available capacity) using the least square method. To describe the diffusion of 
$\mathrm{NH}_{4}{ }^{+}$in N117, the diffusion equation was solved using Fick's law, and the solution was used to fit the experimental curve below.

$$
\frac{\partial C_{N H_{3}(m)}}{\partial t}=D \frac{\partial^{2} C_{N H_{3}(m)}}{\partial z^{2}}
$$

where, $\mathrm{C}=$ the e quivalent $\mathrm{i}$ onic f raction of a mmonium in the m embrane (unity represents full saturation of membrane), $\mathrm{t}=$ time, $\mathrm{z}=$ length in the vertical direction, $\mathrm{D}=$ diffusion coefficient of $\mathrm{NH}_{3(\mathrm{~m})}$ in $\mathrm{N} 117$

To solve this partial differential equation, one initial and two boundary conditions are required. These could be written:

$$
\begin{gathered}
\left.C_{N H 3}\right|_{t=0}=0 \\
\left.C_{N H 3}\right|_{z=0}=1,\left.C_{N H 3}\right|_{z=\infty}=0
\end{gathered}
$$

These could also be written by defining a transformation variable $\eta=\frac{Z}{\sqrt{4 D t}}$ :

$$
\left.C_{N H 3}\right|_{\eta=0}=1,\left.C_{N H 3}\right|_{\eta=\infty}=0
$$

The bounda ry c onditions a re $\mathrm{f}$ ull e xchange $\left(\left.C_{N H 3}\right|_{z=0}=1\right)$ at $\mathrm{t}$ he $\mathrm{m}$ embrane-liquid interface and no exchange $\left(\left.C_{N H 3}\right|_{z=\infty}=0\right)$ infinitely far from the interface. The solution to this diffusion equation is

$$
C_{N H 3}=1-\operatorname{erf}(\eta)
$$

\section{Results and discussion}

3.1. The detection of $\mathrm{NH}_{3}$ 
Ammonia gas is extremely soluble in water, where it ex ists in equilibrium as a molecular form $\left(\mathrm{NH}_{3}\right)$ a ssociated with water and the ionized form $\left(\mathrm{NH}_{4}{ }^{+}\right)$as shown in reaction (6) and (7).

$$
\begin{aligned}
& \mathrm{NH}_{3}(\mathrm{~g}) \leftrightarrow \mathrm{NH}_{3}(\mathrm{aq}) \\
& \mathrm{NH}_{3}(\mathrm{aq})+\mathrm{H}_{2} \mathrm{O} \leftrightarrow \mathrm{NH}_{4}{ }^{+}+\mathrm{OH}^{-} \quad \mathrm{K}_{\mathrm{b}}=1.75 \times 10^{-5}
\end{aligned}
$$

Total ammonia can be obtained from the sum of ammonia $\left(\mathrm{NH}_{3}\right)$ and ammonium $\left(\mathrm{NH}_{4}{ }^{+}\right)$ concentrations and the ratio of $\mathrm{NH}_{3}$ and $\mathrm{NH}_{4}{ }^{+}$in the solution strongly depends on the $\mathrm{pH}$ of solution. F rom reaction (7), a low pH caus es $\mathrm{NH}_{4}{ }^{+}$to dominate in the solution and hence to detect all $\mathrm{NH}_{3}$ by the ammonium ISE, the buffer solution is required to keep the solution acidic. To test the capacity of buffer solution, $997 \mathrm{ppm} \mathrm{NH}_{3}$ in $\mathrm{N}_{2}$ was injected into the solution and the change of $\mathrm{pH}$ in the buffer solution was measured. The $\mathrm{pH}$ remained constant at 4.7 for a total injection of $2500 \mu \mathrm{mol} \mathrm{NH}$. The buffer solution was replaced in these experiments prior to obtaining this total molar dosage of $\mathrm{NH}_{3}$.

To check the collection efficiency a second collection flask was inserted prior to the knock-out so that the $\mathrm{NH}_{3}-\mathrm{N}_{2}$ introduced to the first flask passed to the second flask. The a mount of $\mathrm{NH}_{4}{ }^{+}$was determined by the ISE continuously and the detection results are presented in Fig. 2 for an experiment where 100ppm of $\mathrm{NH}_{3}$ was introduced for 140min without the fuel cell. A material balance for $\mathrm{NH}_{3}$ gave agreement to within the accuracy of the ISE between the inlet and the outlet, and Fig. 2 s hows that the $\mathrm{NH}_{4}{ }^{+}$ concentration in the first flask increased, while the concentration in the second flask did not change. Upon stopping the $\mathrm{NH}_{3}$ injection, the concentration of solution $\mathrm{w}$ as still increasing for 3 min while the re sidual $\mathrm{NH}_{3}$ in the solut ion reacted. The accuracy of 
measurement was $\pm 2 \%$ which is cons istent $w$ ith the accuracy suggested from a $\mathrm{n}$ ISE manufacturer. Since $\mathrm{n}$ o $\mathrm{NH}_{3}$ was de tected in the sec ond flask for the se i nitial experiments, the second flask was removed in subsequent experiments and those material balances agree to the same $\pm 2 \%$ or less.

\subsection{Factors affecting the transport of ammonia}

\subsubsection{The effect of moisture}

Since the performance of fue $1 \mathrm{c}$ ells depend on the hum idity [16], experiments were performed to determine how the moisture affects the transport of ammonia. First, the cell and ISA solutions were allowed to stabilize with neat $\mathrm{N}_{2}$ for 20 min before 100 ppm $\mathrm{NH}_{3}$ was fed to the fuel cell. Fig. 3 shows the amount of ammonia exiting from both sides as the gas s treams to the ce 11 changed from dry $\mathrm{c}$ onditions to $\mathrm{h}$ umid $\mathrm{c}$ onditions. Here, 100\% RH c orresponds to our humid condition. A s shown in Fig. 3, when both electrodes w ere dry (region 1), all of the ammonia i njected e xited $\mathrm{f}$ rom $\mathrm{t}$ he a node, indicating no measureable transfer to the $\mathrm{c}$ athode. A dead time about $2 \mathrm{hr}(0-2 \mathrm{hr}) \mathrm{w}$ as observed and this dead time could indicate accumulation of the $\mathrm{NH}_{3}(\sim 80 \mu \mathrm{mol})$ in the MEA by interacting with available acid sites of the PFSA membrane. This initial dead time $\mathrm{c}$ hanged on di fferent R Hs. Note $\mathrm{t}$ hat $\mathrm{t}$ he ava ilable a cid sites de pend on water contents with water vapor activities in the PFSA membrane.

When the a node gas stream was humidified and the cathode feed remained dry (region 2), ammonia was detected exiting from the cathode after the other certain "dead time" shown by the circles labeled (a) in Fig. 3. The amount of $\mathrm{NH}_{3}$ exiting at the anode decreased, and the difference in amount of $\mathrm{NH}_{3}$ was found captured at the cathode side. The "dead time" ( recall shown by the circles labeled (a) in Fig. 3) corresponds to 
approximately $1 \mathrm{hr}$, and dur ing this tim e a significant a mount of $\mathrm{N} \mathrm{H}_{3}(\sim 40 \mu \mathrm{mol})$ as discussed below with Table 1 was retained in the cell with little exiting from either side. After retaining a measurable amount of $\mathrm{NH}_{3}$ for a bout $1 \mathrm{hr}, \mathrm{NH}_{3}$ exited simultaneously from both e lectrodes. When both streams were changed to a humidified condition (region 3), some additional $\mathrm{NH}_{3}$ was retained $(\sim 40 \mu \mathrm{mol})$ again as indicated by the circles labeled (b).

These results can be explained by the presence of water in membrane enhancing the hydrophilic regions a round the ionic clusters of sul fonic side chains in the PFSA membrane. These regions absorb relatively large amounts of water; thus, $\mathrm{NH}_{3}$ in the gas phase could be di ssolved i $\mathrm{n}$ these $\mathrm{r}$ egions. T he e quilibrium pr ocess gove rning $\mathrm{NH}_{3}$ solubility in MEA can be described by the next reactions:

$$
\begin{gathered}
\mathrm{NH}_{3}(g) \Leftrightarrow \mathrm{NH}_{3}(\mathrm{~m}) \\
\mathrm{NH}_{3}(\mathrm{~m})+\mathrm{H}_{2} \mathrm{O} \Leftrightarrow \mathrm{NH}_{4}^{+}+\mathrm{OH}^{-} \\
\mathrm{NH}_{4}^{+}+\mathrm{H}^{+}-\mathrm{SO}_{3}^{-} \Leftrightarrow \mathrm{NH}_{4}^{+}-\mathrm{SO}_{3}^{-}+\mathrm{H}^{+} \\
\mathrm{H}^{+}+\mathrm{OH}^{-} \Leftrightarrow \mathrm{H}_{2} \mathrm{O}
\end{gathered}
$$

where the notation $(m)$ indicates a form in the membrane without distinguishing the specific species and the $\mathrm{H}^{+}-\mathrm{SO}_{3}{ }^{-}$indicates the proton form of the membrane.

It can be assumed that the reactions in the MEA are fast so that the net reaction is,

$$
\mathrm{NH}_{3}(\mathrm{~m})+\mathrm{H}^{+}-\mathrm{SO}_{3}^{-} \Leftrightarrow \mathrm{NH}_{4}^{+}-\mathrm{SO}_{3}^{-}
$$

The reaction in equation (12) has the following equilibrium constant, K.

$$
K=\frac{C_{N H_{4}^{+}}}{C_{N H_{3}(m)} C_{H^{+}}}
$$


The sites of $\mathrm{H}^{+}$binding with sulfonic groups in the ionomer of the electrode and membrane are converted $\mathrm{t} 0 \mathrm{NH}_{4}^{+}$form. Here, $C_{\mathrm{NH}_{4}^{+}}, C_{\mathrm{NH}_{3}(m)}$ and $C_{\mathrm{H}^{+}}$are $\mathrm{t}$ he concentrations of $\mathrm{NH}_{4}^{+}-\mathrm{SO}_{3}^{-}, \mathrm{NH}_{3}(\mathrm{~m})$, and $\mathrm{H}^{+}-\mathrm{SO}_{3}^{-}$respectively. The concentration of dissolved $\mathrm{NH}_{3}$ in MEA is obtained by the following equation

$$
C_{\mathrm{NH}_{3}(m)}=H^{*} P_{N H 3}
$$

where $P_{N H 3}$ is partial pressure of a mmonia gas in the flow channel; $H^{*}$ is a partition coefficient between the adjacent gas and the membrane. Note that each concentration is within the MEA and total amount of sulfonic acid groups $\left(C_{t}\right)$ are fixed by the original ion exchange capa city (IEC) of the membrane or MEA. Also note, however, that the fraction of e xchangeable s ites $m$ ay de pend on the d egree of hydr ation of the MEA. Assuming a completely hydrated system, the total ammonia absorbed in the membrane is obtained by the sum of physically dissolved $\mathrm{NH}_{3}(\mathrm{~m})$ and the exchanged $\mathrm{NH}_{4}^{+}-\mathrm{SO}_{3}^{-}$.

$$
\begin{gathered}
C_{t}=C_{H^{+}}+C_{N_{4}^{+}} \\
C_{N H_{3}(t)}=C_{N H_{3}(m)}+C_{N_{4}^{+}}=C_{N H_{3}(m)}+K C_{N_{3}(m)} C_{H^{+}}=C_{N H_{3}(m)}\left(1+K C_{H^{+}}\right)
\end{gathered}
$$

In the perfluorosulfonic acid (PFSA) membrane the initial $\mathrm{H}^{+}$concentration is large so the ion-exchange process in reaction (12) is shifted far towards the $\mathrm{NH}_{4}^{+}-\mathrm{SO}_{3}^{-}$. Under the initial highly acidic conditions in the membrane, the ion exchange process appears irreversible and the amount of a mmonium species in the MEA depends on the IEC and the cumulative dosage of $\mathrm{NH}_{3}$. Further, steady state for the injection/transport process is not attained until the IEC is filled by $\mathrm{NH}_{4}{ }^{+}$. Thus, the decrease of $C_{H^{+}}$(or increase of $\left.C_{\mathrm{NH}_{4}^{+}}\right)$is time dependent and this is consistent with Hanson et al.[17] who showed that 
the mass accommodation coefficient of $\mathrm{NH}_{3}$ was essentially unity over the wide $\mathrm{r}$ ange concentration of sulfuric acid.

The apparent loss of vapor phase $\mathrm{NH}_{3}$, shown by the initial dead-time, circles (a) and (b) in Fig. 3, corresponds to a pproximately $160 \mu \mathrm{mol}$ and is probably a r esult of absorption by formation of some $\mathrm{NH}_{4}{ }^{+}$with the sulfonic groups in the MEA. Although the a mount accumulated was si gnificantly less than the measured $210 \mu \mathrm{mol}$ IEC of the $23 \mathrm{~cm}^{2}$ GORE $^{\mathrm{TM}}$ PRIMEA $^{\circledR} 5621$ in the 1 iquid pha se [18], we be lieve the difference results from a $\mathrm{n}$ i ncomplete or pa rtial hydr ation ( sometimes known a s a conditioning process) for the MEA ${ }^{b}$. This de gree of hydration c orrelates $w$ ith the high frequency resistance (HFR) of the MEA as shown in Fig. 4 where the membrane HFR is shown to change significantly as the st ream $\mathrm{w}$ as humidified from a $\mathrm{dr} \mathrm{y} \mathrm{c}$ ondition [16]. The interaction with water was so fast [19], that the resistance dropped suddenly and reached a steady state value of about $0.60 \Omega \mathrm{cm}^{2}$ within 10 mins for region 2 and $0.58 \Omega \mathrm{cm}^{2}$ for region 3. Note that HFR of $0.23,0.13$, a nd $0.096 \Omega \mathrm{cm}^{2}$ are obtained without contamination at $\mathrm{RH}=20,50$, and $80 \%$ respectively, while HFR of $5.27,1.12$, and $0.61 \Omega \mathrm{cm}^{2}$ are obtained with $\mathrm{NH} 3$ contamination at $\mathrm{RH}=20,50$, and $80 \%$ respectively. The fast exchange process of ammonium ion with the membrane and aqueous phase has been verified by Halseid et al. [4]. Thus, the loss of $\mathrm{NH}_{3}$ during the dead times of (a) and (b) should be attributed to the a mount retained by ion exchange in the membrane a nd in the ionomer of both electrodes. Alternatively, some $\mathrm{NH}_{3}$ may be retained somewhere in the flow channel of the graphite plate or the GDL, but this should be negligible due to the very small amount

\footnotetext{
$\mathrm{b}$ In subsequent material balance followed by ion-exchange experiments with only the membrane of this MEA we confirmed, for the dry/dry case, that ion-exchange accounts for the loss or accumulation of $\mathrm{NH}_{3}$ to within the accuracy of the detection device and the material balance measurements.
} 
of water in those locations compared to the potential accumulation in the MEA by ionexchange.

Fig. 5 shows the fraction of $\mathrm{NH}_{3}$ exiting the anode and the cathode with the same flowrate $(150 \mathrm{sccm})$ on both sides. With a humid anode and a dry cathode, approximately $75 \%$ of the injected $\mathrm{NH}_{3}$ left the anode and the remaining $25 \%$ exited the cathode. In the case of humidified feed streams ( $\mathrm{RH}=100 \%$ to both electrodes), approximately $50 \%$ of $\mathrm{NH}_{3}$ exited from each electrode, indicating that more humidification resulted in more crossover of ammonia.

To check that the results in Figs. 3 and 5 were independent of the humidification side, a dif ferent set of experiments was pe rformed. In these experiments, the humidification started from the cathode rather $\mathrm{t}$ han $\mathrm{t}$ he a node. In ot her $\mathrm{w}$ ords, $\mathrm{w} e$ continued to feed the $\mathrm{NH}_{3}$ on the anode side but after the dry/dry condition, the cathode feed stream was humidified, and then after the same duration of time as in region 2 of Figure 3 , both feed streams were changed to the humidified condition. Again, the $\mathrm{NH}_{3}$ was transported to the cathode side only in existence of some humidity as shown by the material balance data in Table 1.

In Table 1, the amount lost was approximately the same (i.e., $43.1 \mu \mathrm{mol}$ for case A a nd $35.1 \mu \mathrm{mol}$ for case B ) for the change from dry/dry to humid/dry or dry/humid. Also, note that the total loss of $\mathrm{NH}_{3}$ from the dry/dry condition was e qual for the two cases. The loss column for the dry/dry case can be used to estimate the accuracy of the material balance detection technique as $0.4 \%$. The loss columns for the humid/dry and humid/humid c onditions indicate the a mount of $\mathrm{NH}_{3}$ accumulated in the ME A during each process. 


\subsubsection{The effect of relative humidity}

The R H of the a node stream was changed to $0,50,80$ a nd $100 \%$ with a dry cathode. A $\mathrm{s}$ found in previous experiments, all the feed $\mathrm{NH}_{3}$ stayed on $\mathrm{t}$ he a node and was collected in the anode flask when both e lectrodes were dry. As the RH of a node increased with a dry $\mathrm{c}$ athode feed, $\mathrm{m}_{\text {ore }} \mathrm{NH}_{3}$ was transported to the $\mathrm{c}$ athode with a maximum flux of $1.48 \times 10^{-10}\left[\mathrm{molcm}^{-2} \mathrm{~s}^{-1}\right]$ as indicated in Fig. 6 (a). The change of RH for both streams also led to the increase of $\mathrm{NH}_{3}$ transport (Fig. 6 (b)) with a maximum of $2.3 \times 10^{-10}\left[\mathrm{molcm}^{-2} \mathrm{~s}^{-1}\right]$ at $100 \%$ RH. The trends seen in Fig. 6 are consistent with the well known significant increase of $\mathrm{w}$ ater con tent with increasing water va por activity [20]. Thus, e ven though the $\mathrm{NH}_{3}$ gas in $\mathrm{t}$ he $\mathrm{N}_{2}$ with $\mathrm{RH} 50 \%$ is in the vapor pha se, the transport of $\mathrm{NH}_{3}$ through the ME A increases because of the increase of available acid sites due to water absorption in the MEA. If the ammonia (hydrophilic) diffuses mainly through the hydrophilic domains with $\mathrm{SO}_{3}^{-}$group and not the hydrophobic domains with Teflon backbone, adding more moisture increases the swelling of hydrophilic domain and the s olubility of a mmonia in that domain. Water m olecules in the interfacial $r$ egions produce the hydrated shell and branched network from ion-dipole interaction and lead to the easier transport of $\mathrm{NH}_{3}[13,14,21]$.

\subsubsection{The effect of cathode flowrate}

Fig. 7 shows the effect of changing the cathode flowrate on the transport of $\mathrm{NH}_{3}$. Here, the anode flowrate was constant at $150 \mathrm{sccm}$ and the cathode flowrate was increased to $1,3,6,8$, and 9 times greater than that of the anode flowrate. The high flowrate of the 
cathode resulted in an increased $\mathrm{NH}_{3}$ mole flux to the cathode, probably due to a decrease in the partial pressure of $\mathrm{NH}_{3}$ in the cathode, which increased the concentration gradient across the MEA. To calculate the diffusion coefficient of ammonia through MEA in the following section, we chose the ratio of cathode/anode flowrate as 8 (i.e., anode/cathode flowrate $=150 / 1200 \mathrm{sccm}$ ) so that we could assume the partial pressure of ammonia in the cathode to be zero. In other words, ammonia transport at OCV condition depends on the concentration gradient between anode and cathode.

\subsection{Transport mechanism of ammonia in membrane}

We be lieve the evide nce above indicates that at OCV, when a mmonia ga s is introduced to the MEA, ammonia is disso lved in the ME A according to a pa rtition coefficient, which is dependent on the $\mathrm{RH}$. The dissolved $\mathrm{NH}_{3}$ reacts with $\mathrm{H}^{+}$quickly, leading to the formation of $\mathrm{NH}_{4}{ }^{+}$as the protonated species in the ionomer. This reaction proceeds un til all of the available proton sites at the particular $\mathrm{RH}$ are fully exchanged with $\mathrm{NH}_{3}$. Then, the dissolved $\mathrm{NH}_{3}$ crosses over to the other side through hydrophilic domains. At the boundary of the membrane and gas phase on the cathode, the transported $\mathrm{NH}_{3}(\mathrm{~m})$ converts again to $\mathrm{NH}_{3}(\mathrm{~g})$ according to the value of the partition coefficient and then comes out of the cell in the gas phase. Thus, $\mathrm{NH}_{3}(\mathrm{~g}), \mathrm{NH}_{3}(\mathrm{~m})$, and the $\mathrm{NH}_{4}{ }^{+}$form are equilibrated throughout the MEA but a steady state is obtained which involves the diffusion of $\mathrm{NH}_{3}$ through $\mathrm{t}$ he $\mathrm{MEA} \mathrm{f}$ rom $\mathrm{t}$ he anode to the $\mathrm{c}$ athode, after a $1 \mathrm{o} f$ the available proton sites $\mathrm{h}$ ave exc hanged. The s elf di ffusion of $\mathrm{NH}_{4}{ }^{+}$ions $\mathrm{c}$ an a lso be suggested, but the diffusion of molecules through the membrane after exc hange is the limiting factor of $\mathrm{NH}_{3}$ transport rather than $\mathrm{NH}_{4}{ }^{+}$[22]. 
To de scribe these phe nomena simply, we be gin w ith a 1 -D time de pendent material balance which includes reaction of the $\mathrm{NH}_{3}$ with the acid sites in the ionomer of the MEA (equation 12) and disregards any gradients in the axial direction (i.e., down the channel 1 ength) ${ }^{c}$. O ur de scription above indi cates th at there a re tw o distinct $s$ ets of governing e quations s eparated by $t$ he extent of i on-exchange. F or the first set which occurs prior to complete ion-exchange, the time dependent accumulation of $\mathrm{NH}_{3}$ in the MEA is governed by the very fast reaction rate (reaction 18). For the second set, all of the available $\mathrm{H}^{+}$sites have reacted and a steady state oc curs so that the flux of $\mathrm{NH}_{3}$ is constant and dependent on the concentration gradient in the gas streams (i.e. reaction 19).

$$
\begin{gathered}
\frac{d C_{N H_{3}(m)}}{d t}=-\frac{d N_{N H_{3}(m)}}{d z}+R \\
\frac{d C_{H^{+}}}{d t}=R \\
0=\frac{d N_{N H_{4}{ }^{+}}}{d z}
\end{gathered}
$$

For the later set of equations, the flux of dissolved ammonia is obtained by integrating equation (19) with a constant di ffusion c oefficient and a zer o cat hode conc entration. Recall that the ammonia mole flux from anode to cathode reached steady state at the ratio of flowrate $\mathrm{A} / \mathrm{C}=1 / 8$ as shown in Fig. 7.

$$
N_{\mathrm{NH}_{3}(m)}=D_{\mathrm{NH}_{3}} \frac{C_{\mathrm{NH}_{3}(\mathrm{~m})}-0}{l}=D_{\mathrm{NH}_{3}} \frac{H^{*} P_{\mathrm{NH}_{3}}}{l}
$$

\footnotetext{
${ }^{c}$ This approximation will be analyzed in subsequent publication $s$ and it should be recognized that it ignores the variation or the crossover flux due to accumulation of partial pressure of $\mathrm{NH}_{3}$ in the cathode stream and it lumps the electrode layers with the membrane for the thickness calculations.
} 
where $N_{\mathrm{NH}_{3}(\mathrm{~m})}$ is the flux of a mmonia from the a node to the c athode; and $l$ is tot al distance $\mathrm{f}$ or a mmonia diffusion which i ncludes, $\mathrm{f}$ or $\mathrm{t}$ his $\mathrm{s}$ imple a pproximation, $\mathrm{t}$ he thickness of the catalyst layers and the membrane. In other words, $\mathrm{NH}_{3}$ transport behaves like the diffusion-solubility mechanism and the data collected here as shown in Fig. 8, indicate that the flux had a linear relation with the ammonia concentration depending on the RH. Thus, the diffusion coefficient of ammonia through the MEA can be calculated as:

$$
D_{\mathrm{NH}_{3}}=\frac{N_{\mathrm{NH}_{3}(\mathrm{~m})}}{P_{\mathrm{NH}_{3}}} \frac{H^{*}}{l}
$$

Note that a partition coefficient of a mmonia in the MEA is s imilar to Henry's 1 aw constant $\left(\mathrm{molcm}^{-3} \mathrm{~atm}^{-1}\right)$ in water, which for a mmonia de pends on temperature and is expressed by [23]:

$$
H^{*}=10^{-3} \exp \left(-7.44+\frac{3214.4}{T}\right)
$$

Thickness of MEA for GORE $^{\mathrm{TM}}$ PRIMEA $^{\circledR}$ Series 5710 was measured as $25 \mu \mathrm{m}$. For these assum ptions, the di ffusion coefficients of a mmonia at the different RHs (i.e., $\mathrm{RH}=50$ a nd $80 \%$ ) are listed in Table 2. T imashev et al . [22] reported the $D_{\mathrm{NH}_{3}}$ (i.e., $3.5 \times 10^{-7} \mathrm{~cm}^{2} \mathrm{~s}^{-1}$ ) obtained in PFSA polymer hollow-fibers at $23^{\circ} \mathrm{C}$ (not report humidity). The reported diffusion coefficient is 1-order lower than ours (i.e., $2.4 \times 10^{-6} \mathrm{~cm}^{2} \mathrm{~s}^{-1}$ at $\mathrm{RH}=$ $50 \%$ and $3.4 \times 10^{-6} \mathrm{~cm}^{2} \mathrm{~s}^{-1}$ at $\mathrm{RH}=80 \%$ ) and obtained at higher temperature (i.e., $\mathrm{T}=80^{\circ} \mathrm{C}$ ). Also, $D_{\mathrm{NH}_{3}}$ measured by ex-situ mass-uptake method obtained in Nafion ${ }^{\circledR}$ membranes 
(N117) were $2.6 \times 10^{-6} \mathrm{~cm}^{2} \mathrm{~s}^{-1}$ and $1.1 \times 10^{-5} \mathrm{~cm}^{2} \mathrm{~s}^{-1}$ at $23^{\circ} \mathrm{C}$ and $70^{\circ} \mathrm{C}$ respectively (shown in Table 3), which are reasonable when compared with reported values of diffusivities for other cations in $\mathrm{N} 117$ (e.g., $1.03 \times 10^{-6} \mathrm{~cm}^{2} \mathrm{~s}^{-1}$ for $\mathrm{Na}^{+}, 1.4 \times 10^{-6} \mathrm{~cm}^{2} \mathrm{~s}^{-1}$ for $\mathrm{Li}^{+}$at $23^{\circ} \mathrm{C}$ ) $[24,25]$. These ex-situ values represent $100 \%$ of RH condition because they are obtained in liquid phase and not in gas phase, thereby, we can conclude that the diffusion of $\mathrm{NH}_{3}$ in MEA or membrane from anode to cathode logarithmically increased as RHs increased. Also, the $\mathrm{h}$ igher temperature $\left(80^{\circ} \mathrm{C}\right) 1$ eads to 1 -order faster diffusion of $\mathrm{N} \mathrm{H}_{3}$ than the diffusion a $t$ room temperature. These $r$ esults also $s$ upport the di ffusion-solubility mechanism. That is, the important role of water for the diffusion of $\mathrm{NH}_{3}$ through MEA or membrane can be considered as we described above. Note that the fuel cell electrode has an ionomer w ith $\mathrm{Pt} / \mathrm{C} \mathrm{c}$ atalyst and the $\mathrm{i}$ onomer has a larger surf ace a rea, which may increases the dissolution of $\mathrm{NH}_{3}$, even if the ionomer has the same chemical structure as the PFSA membrane. However, both ex-situ a nd i n-situ measurements are st ill comparable because the iono mer in the electrode has typically 1 order less $(1 / 10)$ acid capacity than the membrane capacity.

\section{Conclusions}

The transport of $\mathrm{NH}_{3}$ was studied at $\mathrm{OCV}$ in a $\mathrm{N}_{2} / \mathrm{N}_{2}$ system. $\mathrm{NH}_{3}$, added as the anode contaminant, was transported to the cathode stream, but onl y i n e xistence of moisture in the MEA, which is independent of the feed from either the anode or the cathode. $\mathrm{NH}_{3}$ appears to dissolve in the water in the MEA, exchange with the acid sites, and generate the $\mathrm{NH}_{4}{ }^{+}$form of the ionomer while it moves through the membrane to the 
cathode. I on exchange occurred prior $\mathrm{to}$ the obs ervation of $\mathrm{NH}_{3}$ transport and all available proton sites appear to be exchanged by $\mathrm{NH}_{4}{ }^{+}$before the transport. $\mathrm{NH}_{3}$ transport was observed at RHs less than $100 \%$. The mole flux of $\mathrm{NH}_{3}$ through MEA at steady state increased more at higher R H conditions. Also, the increase of cathode flowrate at the fixed anode flowrate induced an increase in the mole flux of ammonia through MEA or membrane to the cathode and reached steady state, which al lowed us to obtain the diffusivity of $\mathrm{NH}_{3}$ through MEA or m embrane. Finally, the r esults showed that the transport of a mmonia is gove rned by the combined mechanisms of diffusion-solubility and di ffusion-reaction in the $\mathrm{N}_{2} / \mathrm{N}_{2}$ system for R Hs gr eater $t$ han $50 \%$. Diffusion coefficients of $\mathrm{NH}_{3}$ at $\mathrm{T}_{\text {cell }}=80^{\circ} \mathrm{C}$ were also calculated at different values of $\mathrm{RH}\left(2.4 \times 10^{-6}\right.$ $\mathrm{cm}^{2} \mathrm{~s}^{-1}$ at $\mathrm{RH}=50 \%$ a nd $3.4 \times 10^{-6} \mathrm{~cm}^{2} \mathrm{~s}^{-1}$ at $\mathrm{RH}=80 \%$ ). Also, di ffusion c oefficients obtained by ex-situ mass uptake in N117 reported to compare.

\section{Acknowledgments}

The a uthors gr atefully a cknowledge $\mathrm{t}$ hat $\mathrm{t}$ his $\mathrm{w}$ ork $\mathrm{w}$ as $\mathrm{s}$ upported unde $\mathrm{r}$ Department of E nergy Grant D E-FC36-06GO86041. CARBEL, GORE-SELECT, PRIMEA, and GORE designs are trademarks of W. L. Gore \& Associates, Inc. 


\section{References}

[1] http://www1.eere.energy.gov/hydrogenandfuelcells/mypp/pdfs/appendix_c.pdf.

[2] F. A. Uribe, S. Gottesfeld, T. A. Zawodzinski, J. of the Electrochem. Soc. 149 (2002) A293.

[3] H. Soto, W. Lee, J. W. Van Zee, M. Murthy, Electrochem. and Solid-State Lett. 6 (2003) A133.

[4] R. Halseid, P. J. S. Vie, and R. Tunold, J. Electrochem. Soc, 151 (2004) A381

[5] R. Halseid, P. J. S. Vie, R. Tunold, J. Power Sources 154 (2006) 343.

[6] R. Halseid, T. Bystron, R. Tunold, Electrochim. Acta 51 (2006) 2737.

[7] R. Halseid, J. S. Wainright, R. F. Savinell, R. Tunold, J. Electrochem. Soc. 154 (2007) B263.

[8] F. A. Uribe and T. A. Zawodzinski Jr., "The effects of fuel impurities on PEM Fuel Cell performance," paper \# 339 presented at the $200^{\text {th }}$ ECS meeting in San Francisco, CA Sep. 2-7 (2001)

[9] K. Hongsirikarn, J. G. Goodwin, S. Greenway, S. Creager, J. Power Sources 195 (2010) 30.

[10] K. Honsirikarn, X. Mo, and J. G. Goodwin, J. Power Sources 195 (2010) 3416

[11] X. Y. Zhang, U. Pasaogullari, T. Molter, Int. J. Hydrogen Energy,34 (2009) 9188.

[12] A. Bhown and E. L. Cussler, J. Amer. Chem. Soc. 113 (1991) 742.

[13] Y. K. He and E. L. Cussler, J. Mem. Sci. 68 (1992) 43.

[14] V. Tricoli and E. L. Cussler, J Mem. Sci. 104 (1995) 19.

[15] F. Helfferich, "Ion Exchange," McGraw-Hill Book Co., Inc., NY (1962)

[16] T. J. P. Freire and E. R. Gonzalez, J Electroanal. Chem. 503 (2001) 57.

[17] D. Hanson and E. Kosciuch, J Phys. Chem. A 107 (2003) 2199.

[18] M. Ohashi, Ph. D. dissertation, University of South Carolina, (2008)

[19] T. A. Zawodzinski, M. Neeman, L. O. Sillerud, S. Gottesfeld, J.Phys. Chem.;95 (1991) 6040.

[20] T. A. Zawodzinski, C. Derouin, S. Radzinski, R. J. Sherman, V.T. Smith, T. E. Springer, and S. Gottesfeld, J Electrochem. Soc.140 (1993) 1041.

[21] A. V. Vorobiev and L. N. Beckman, Russ.Chem. Bull.51 (2002) 275.

[22] S. F. Timashev, A. V. Vorobiev, V. I. Kirichenko, Y. M. Popkov, V. I. Volkov, R. 
R. Shifrina, A. Y. Lyapunov, A. G. Bondarenko, and L. P. Bobrova, J Mem. Sci. 59 (1991) 117.

[23] Q. Shi Q,P. Davidovits, J. T. Jayne, D. R. Worsnop, C. E. Kolb, J Phys. Chem. A 103 (1999) 8812.

[24] S. Morihiro, N. Arimura, K. Hayamizu, and T. Okada, J. Phys. Chem. B, 108 (2004) 16064 .

[25] A. Goswami, A. Acharya, and A. K. Pandey, J. Phys. Chem. B 105 (2001) 9196.

[26] H. L. Yeager and B. Kipling, J. Phys. Chem. 83 (1979) 1836.

[27] H. L. Yeager and A. Steck, J. Electrochem. Soc. 128 (1981) 1880. 
Table 1. Total injection a nd de tection $\mathrm{f}$ rom bot $\mathrm{h}$ e lectrodes for di fferent anode and cathode humidity w ith $100 \mathrm{ppm} \mathrm{N} \mathrm{H} / \mathrm{N}_{2}$ (Flowrate $\mathrm{A} / \mathrm{C}=150 \mathrm{sccm}, \mathrm{T}_{\text {cell }}=70{ }^{\circ} \mathrm{C}$, $\mathrm{RH}=100 \%$ ). The loss column for the dry/dry case can be used to estimate the accuracy of the material balance detection technique as $0.4 \%$. The loss columns for the Humid/Dry and Humid/Humid conditions indicate the amount of $\mathrm{NH}_{3}$ accumulated in the MEA

\begin{tabular}{|c|c|c|c|c|c|c|c|}
\hline & \multirow{2}{*}{\multicolumn{2}{|c|}{ Condition }} & \multirow{3}{*}{ Time $[\mathrm{h}]$} & \multicolumn{4}{|c|}{$\mathrm{NH}_{3}(\mu \mathrm{mol})$} \\
\hline & & & & In & & & \multirow{2}{*}{ Loss } \\
\hline & Anode & Cathode & & Anode & Anode & Cathode & \\
\hline \multirow{3}{*}{ A } & Dry & Dry & 30 & 1204.5 & 1210.1 & 0.0 & -5.6 \\
\hline & Humid & Dry & 15 & 602.3 & 402.2 & 157 & 43.06 \\
\hline & Humid & Humid & 14 & 565.5 & 264.2 & 260.2 & 41.1 \\
\hline \multirow{3}{*}{ B } & Dry & Dry & 30 & 1204.5 & 1204.1 & 0.0 & 0.4 \\
\hline & Humid & Dry & 15 & 602.3 & 369.0 & 198.2 & 35.1 \\
\hline & Humid & Humid & 14 & 565.5 & 263.0 & 252 & 50.5 \\
\hline
\end{tabular}


Table 2. D iffusion coefficients of ammonia in PRIMEA ${ }^{\circledR} 5710$ at $\mathrm{T}_{\text {cell }}=80^{\circ} \mathrm{C}$ (obtained in Fig. 8)

\begin{tabular}{c|c|c|c|c}
\hline \multirow{2}{*}{$\mathrm{RH}[\%]$} & $\begin{array}{c}\mathrm{C} \\
{[\mathrm{ppm}]}\end{array}$ & $\begin{array}{c}\mathrm{P}_{\mathrm{NH} 3} \\
{[\mathrm{~atm}]}\end{array}$ & $\begin{array}{c}\mathrm{N}_{\mathrm{NH} 3} \times 10^{-10} \\
{\left[\mathrm{molcm}^{-2} \mathrm{~s}_{-1}\right]}\end{array}$ & \multirow{2}{*}{$\mathrm{D}\left[\mathrm{cm}^{2} \mathrm{~s}^{-1}\right]$} \\
\hline \multirow{3}{*}{50} & 100 & $8.50 \mathrm{E}-05$ & 1.3 & \multirow{2}{*}{$2.4( \pm 0.15) \times 10^{-6}$} \\
\cline { 2 - 5 } & 200 & $1.70 \mathrm{E}-04$ & 2.4 & \\
\cline { 2 - 5 } & 300 & $2.50 \mathrm{E}-04$ & 3.5 & \multirow{2}{*}{$3.4( \pm 0.10) \times 10^{-6}$} \\
\cline { 2 - 5 } 80 & 100 & $7.60 \mathrm{E}-05$ & 1.6 & \\
\cline { 2 - 5 } & 200 & $1.50 \mathrm{E}-04$ & 3.1 & \\
\cline { 2 - 5 } & 300 & $2.30 \mathrm{E}-04$ & 4.6 & \\
\hline
\end{tabular}


Table 3. Comparison of literature value with diffusion coefficients of ammonia through GORE $^{\mathrm{TM}}$ PRIMEA $^{\circledR} 5710$ at $\mathrm{T}_{\text {cell }}=80^{\circ} \mathrm{C}$ and in plane of $\mathrm{N} 117$ for different temperatures

\begin{tabular}{c|c|c|c}
\hline \multirow{2}{*}{ Methods } & \multirow{2}{*}{$\mathrm{RH}$} & \multicolumn{2}{|c}{$\mathrm{D}_{\mathrm{NH} 3}\left[\mathrm{~cm}^{2} \mathrm{~s}^{-1}\right]$} \\
\cline { 3 - 4 } & $50 \%$ & $4.1 \times 10^{-7}$ & $80{ }^{\circ} \mathrm{C}$ \\
\hline $\begin{array}{c}\text { In-situ single cell mass } \\
\text { balance technique }\end{array}$ & $80 \%$ & $1.0 \times 10^{-6}$ & $3.4 \times 10^{-6}$ \\
\hline \multirow{2}{*}{$\begin{array}{c}\text { Ex-situ mass-uptake } \\
\text { method in N117 }\end{array}$} & $100 \%$ & $2.6 \pm 0.3 \times 10^{-6}$ & $1.1 \pm 0.2 \times 10^{-5}$ \\
\cline { 3 - 4 } & & $\mathrm{D}_{\mathrm{Na}+}=5.0 \pm 0.4 \times 10^{-6}$ & $\mathrm{D}_{\mathrm{Na}+}=1.5 \pm 0.2 \times 10^{-5}$ \\
\hline $\begin{array}{c}\text { Gas permeability } \\
\text { measurement }\end{array}$ & $\mathrm{N} / \mathrm{A}$ & $3.5 \times 10^{-7}[22]$ & \\
\hline $\begin{array}{c}\text { Pulsed-field gradient } \\
\text { nuclear magnetic } \\
\text { resonance spectroscopy }\end{array}$ & $100 \%$ & $\mathrm{D}_{\mathrm{Na}+}=1.03 \times 10^{-6}[24]$ & \\
\hline $\begin{array}{c}\text { Nonstationary } \\
\text { radiotracer diffusion } \\
\text { method }\end{array}$ & $100 \%$ & $\mathrm{D}_{\mathrm{Li}+}=1.4 \times 10^{-6}[25]$ & \\
\hline $\begin{array}{c}\text { Radiotracer permeation } \\
\text { man }\end{array}$ & $100 \%$ & $\mathrm{D}_{\mathrm{Na}+}=1.7 \times 10^{-6}[26,27]$ & \\
\hline
\end{tabular}




\section{List of Figures}

Fig. 1. Schematic of the material balance experimental apparatus.

Fig. 2. Comparison of i njection a nd c ollection of $\mathrm{N} \mathrm{H}_{3}$ with 100 ppm $\mathrm{N} \mathrm{H}_{3}$ in $\mathrm{N}_{2}$; Flowrate $=150 \mathrm{sccm}$ of mixture $\mathrm{NH}_{3} / \mathrm{N}_{2}$ tank and the UHP $\mathrm{N}_{2}$ tank (Dry injection, Preheated to $\left.90^{\circ} \mathrm{C}\right)$.

Fig. 3. Amount of $\mathrm{NH}_{3}$ detected from both sides of the PEMFC at OCV show ing the effect of a node humidity with $100 \mathrm{ppm} \mathrm{N} \mathrm{H}_{3} / \mathrm{N}_{2}$. A/C = Anode/Cathode. Regions: (1) $\mathrm{A} / \mathrm{C}=$ dry/dry (2) A/C = humid/dry (3) A/C = humid/humid (Flowrate A/C = 150sccm, $\left.\mathrm{T}_{\text {cell }}=70^{\circ} \mathrm{C}, \mathrm{RH}=100 \%\right)$.

Fig. 4. Change of HFR with humidity changes to both electrodes: flowrate $A / C=150 \mathrm{sccm}$, $\mathrm{T}_{\text {cell }}=70^{\circ} \mathrm{C}, \mathrm{RH}=100 \%$. The HFR was $0.096 \Omega \mathrm{cm}^{2}$ after conditioning.

Fig. 5. The fraction of $\mathrm{NH}_{3}$ exiting each electrode during conditions of Region (2) and Region (3) in Fig. 3.

Fig. 6. Effect of relative humidity $(\mathrm{RH})$ on the $\mathrm{NH}_{3}$ flux across the MEA; (a) The effect of anode RH with a dry cathode; (b) The effect of $\mathrm{RH}$ on both electrodes; $100 \mathrm{ppm} \mathrm{NH}$, flowrate $\left.\mathrm{A} / \mathrm{C}=150 \mathrm{sccm}, \mathrm{T}_{\text {cell }}=70^{\circ} \mathrm{C}\right)$.

Fig. 7. $\mathrm{T}$ he de pendence of the $\mathrm{NH}_{3}$ flux across the ME $\mathrm{A}$ on $\mathrm{c}$ hanges in the cathode flowrate at constant anode feed; 100 and $300 \mathrm{ppm} \mathrm{NH}_{3}$ in $\mathrm{N}_{2}$, Anode flowrate $=150 \mathrm{sccm}$, Gore $^{\mathrm{TM}}$ PRIMEA $^{\circledR} 5710$ at $\mathrm{T}_{\text {cell }}=80^{\circ} \mathrm{C}, \mathrm{RH}=50$ and $80 \%$.

Fig. 8. Verification of diffusion-solubility mechanism at $\mathrm{OCV}$; 100 and $300 \mathrm{ppm} \mathrm{NH}_{3}$ in $\mathrm{N}_{2}$, Flowrate $\mathrm{A} / \mathrm{C}=150 / 1200 \mathrm{sccm}$, Gore ${ }^{\mathrm{TM}} \mathrm{PRIMEA}^{\circledR} 5710$ at $\mathrm{T}_{\text {cell }}=80^{\circ} \mathrm{C}$; (a) $\mathrm{RH}=50 \%$ (b) $\mathrm{RH}=80 \%$. 


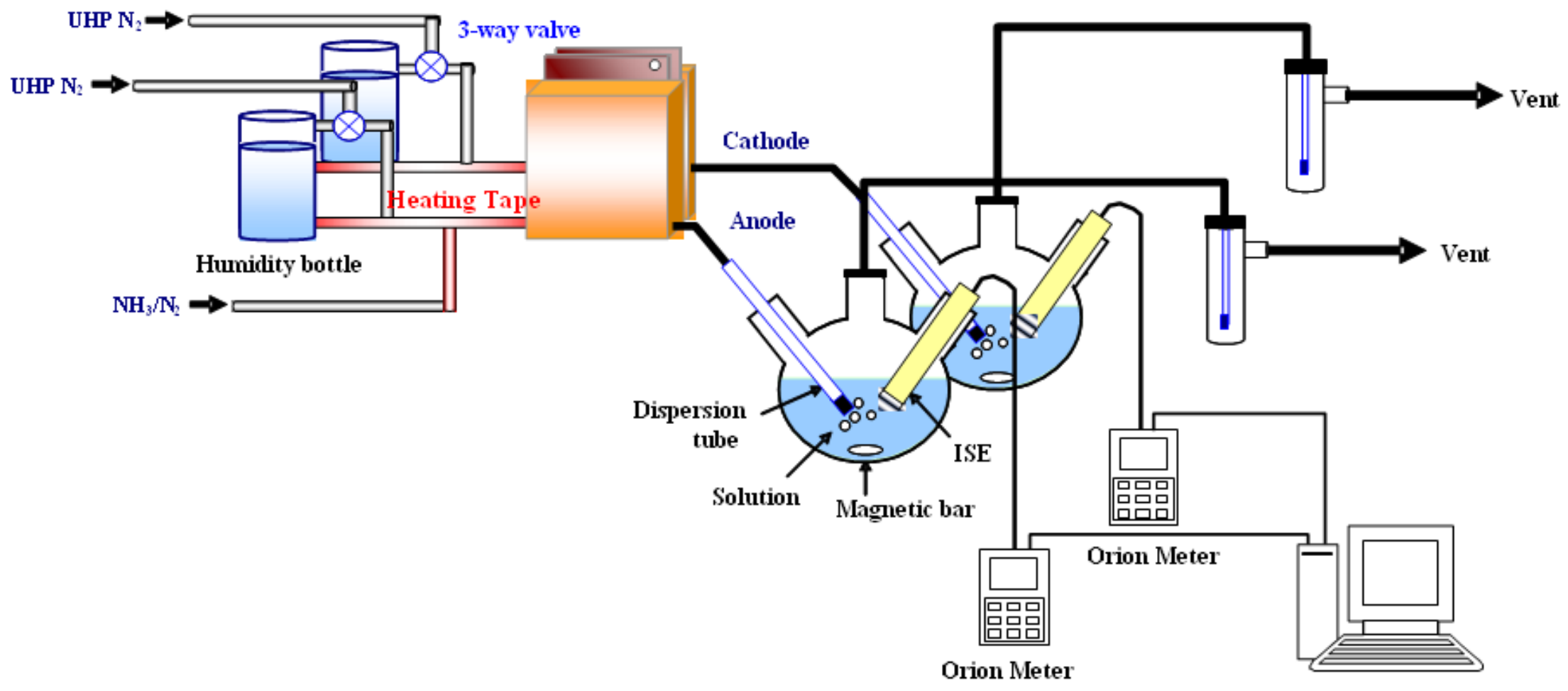

Computer for recording

Fig. 1. Schematic of the material balance experimental apparatus 


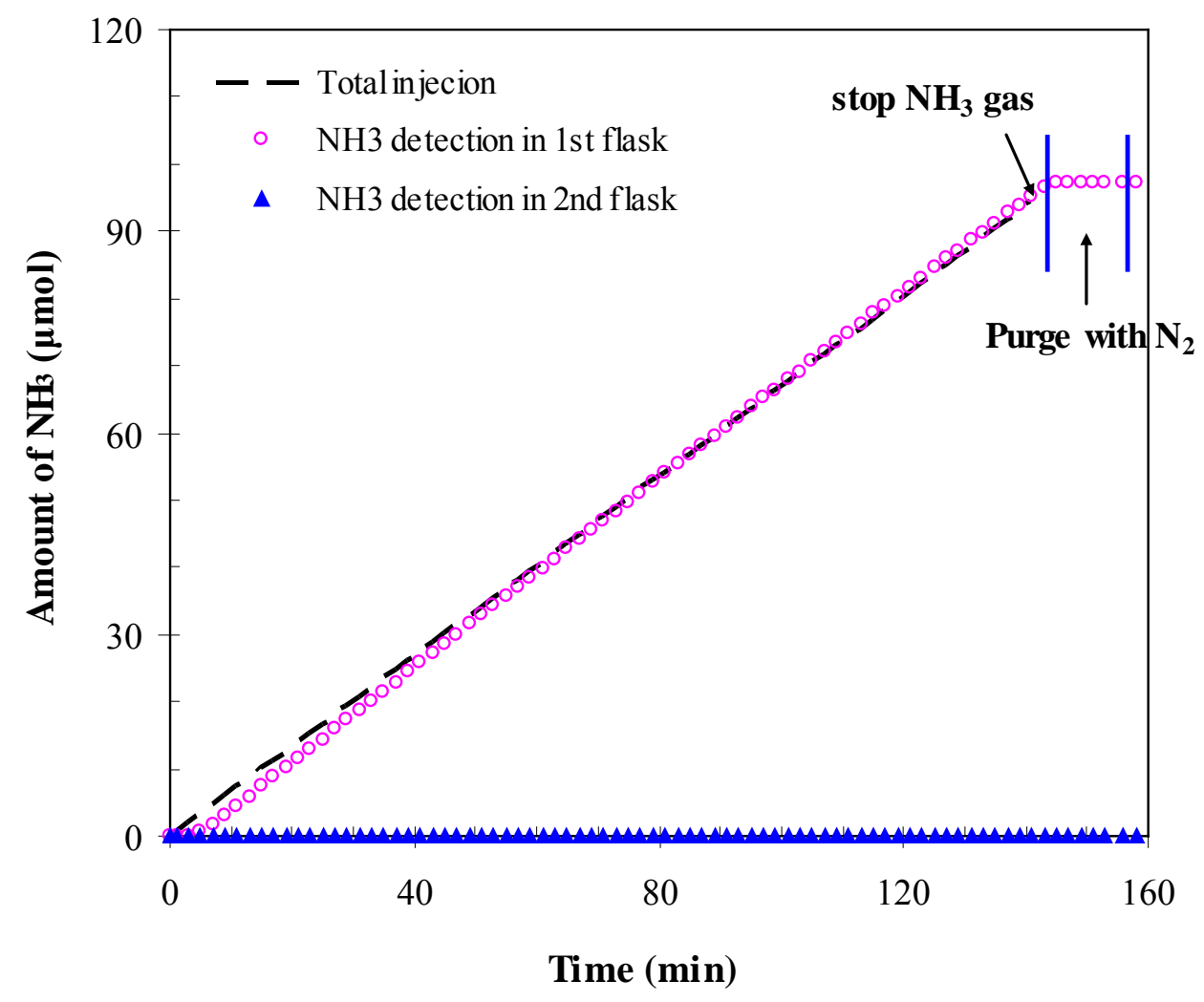

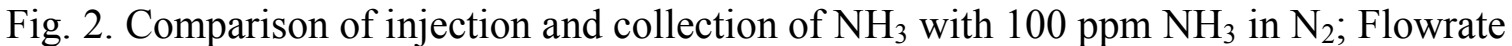
$=150 \mathrm{sccm}$ of mixture $\mathrm{NH}_{3} / \mathrm{N}_{2}$ tank and the UHP $\mathrm{N}_{2}$ tank (Dry injection, Pre-heated to $\left.90^{\circ} \mathrm{C}\right)$. 


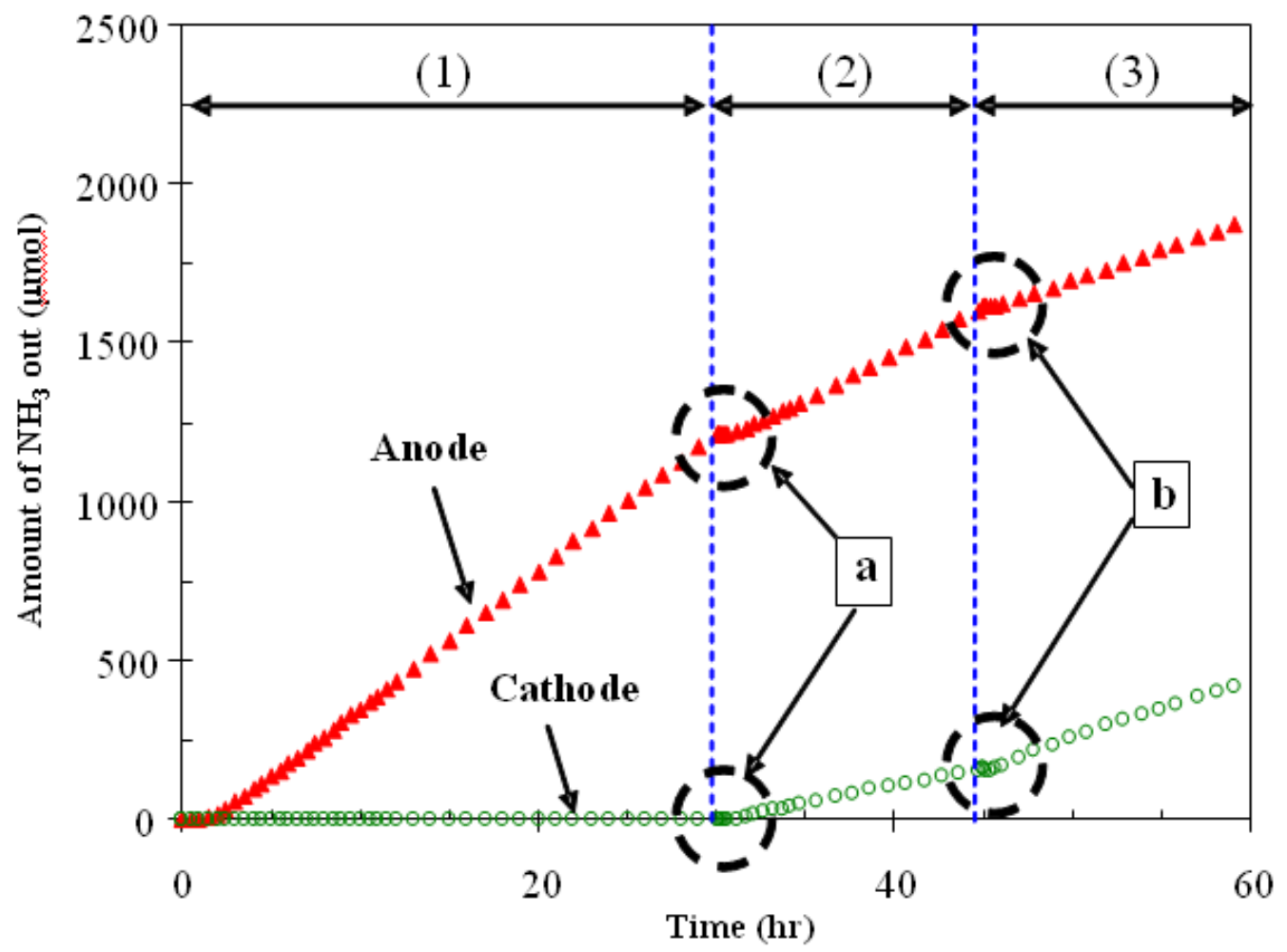

Fig. 3. Amount of $\mathrm{NH}_{3}$ detected from both sides of the PEMFC at OCV show ing the

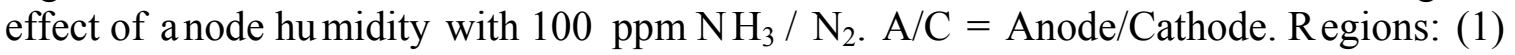
$\mathrm{A} / \mathrm{C}=\operatorname{dry} / \operatorname{dry}(2) \mathrm{A} / \mathrm{C}=$ humid/dry (3) $\mathrm{A} / \mathrm{C}=$ humid/humid: flowrate $\mathrm{A} / \mathrm{C}=150 \mathrm{sccm}$, $\mathrm{T}_{\text {cell }}=70^{\circ} \mathrm{C}, \mathrm{RH}=100 \%$ 


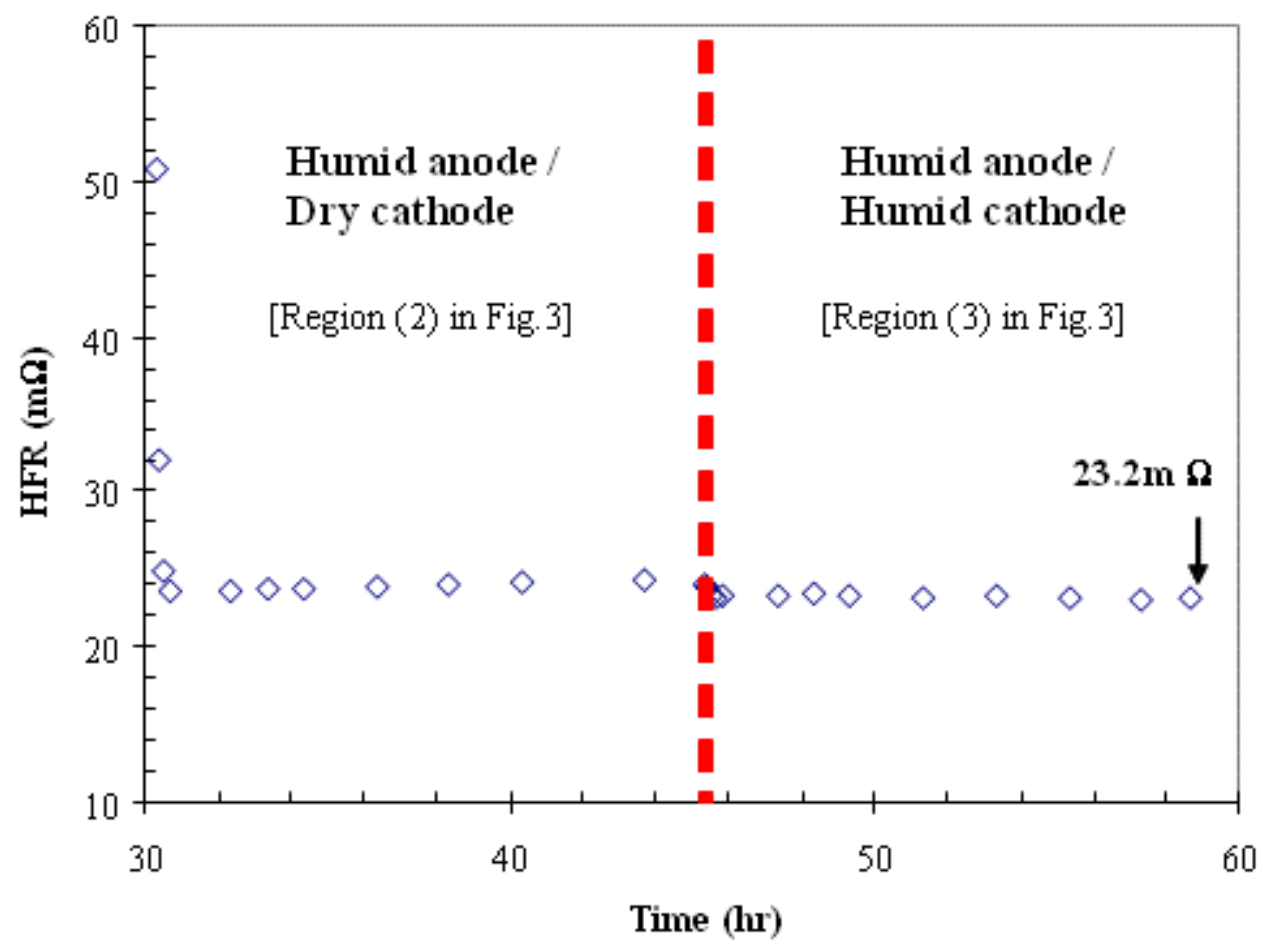

Fig. 4. Change of HFR with humidity changes to both electrodes: flowrate $\mathrm{A} / \mathrm{C}=150 \mathrm{sccm}$, $\mathrm{T}_{\text {cell }}=70^{\circ} \mathrm{C}, \mathrm{RH}=100 \%$. The HFR was $0.096 \Omega \mathrm{cm}^{2}$ after conditioning 


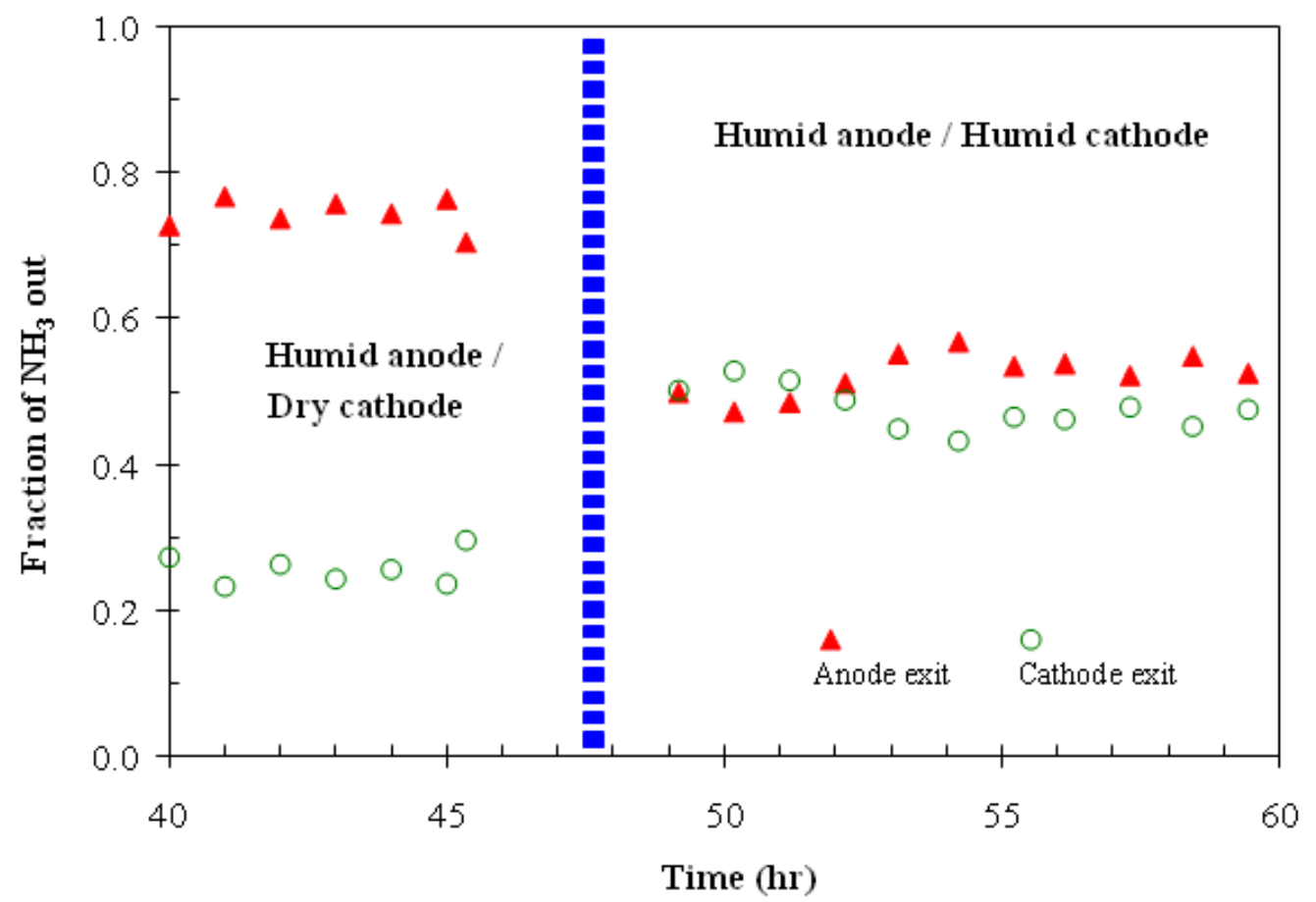

Fig. 5. The fraction of $\mathrm{NH}_{3}$ exiting each el ectrode during conditions of Region (2) and Region (3) in Fig. 3. 

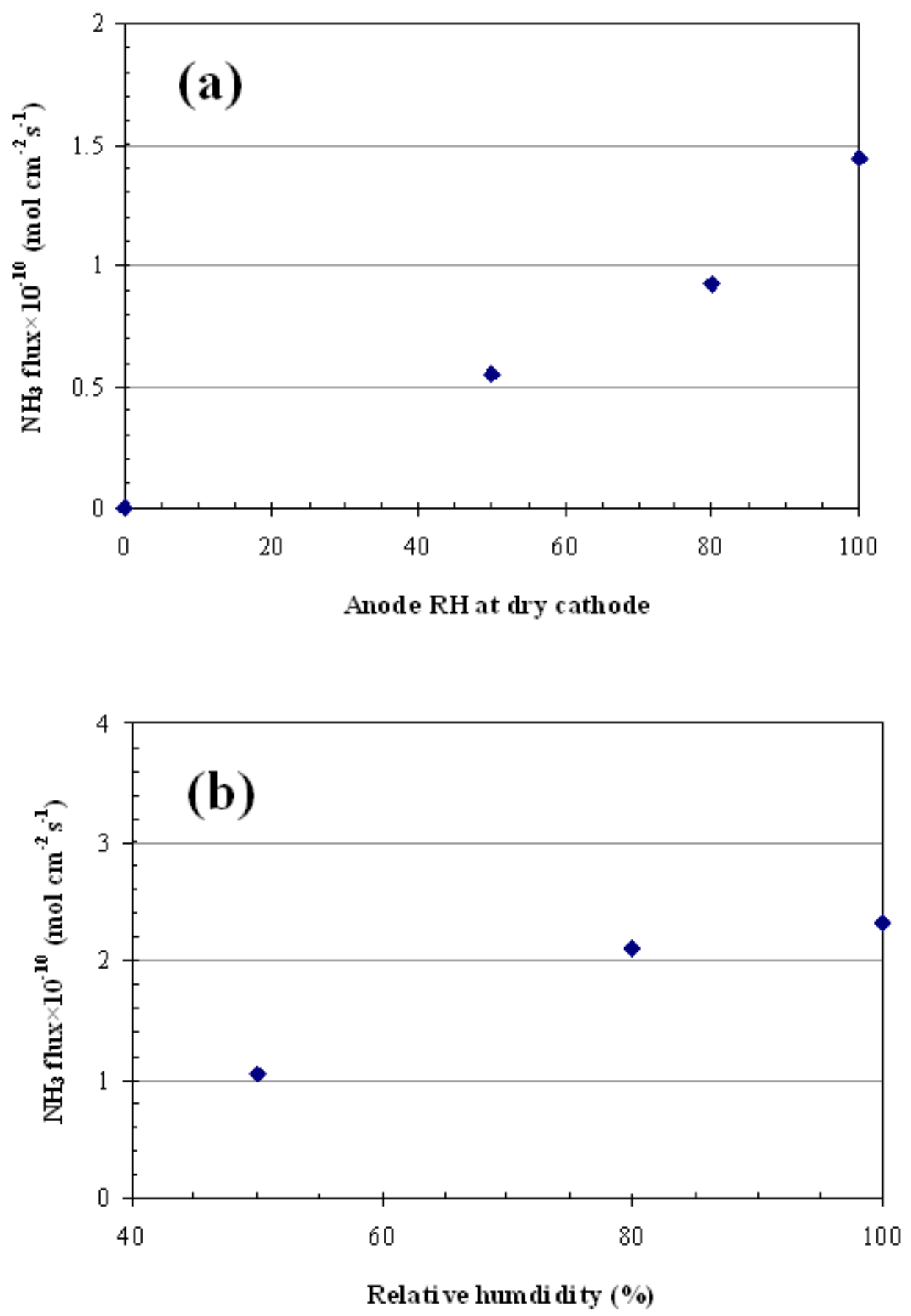

Fig. 6. Effect of relative humidity (RH) on the $\mathrm{NH}_{3}$ flux across the MEA; (a) The effect of anode RH with a dry cathode; (b) The effect of $\mathrm{RH}$ on both electrodes; $100 \mathrm{ppm} \mathrm{NH}$, flowrate $\mathrm{A} / \mathrm{C}=150 \mathrm{sccm}, \mathrm{T}_{\text {cell }}=70^{\circ} \mathrm{C}$ ) 


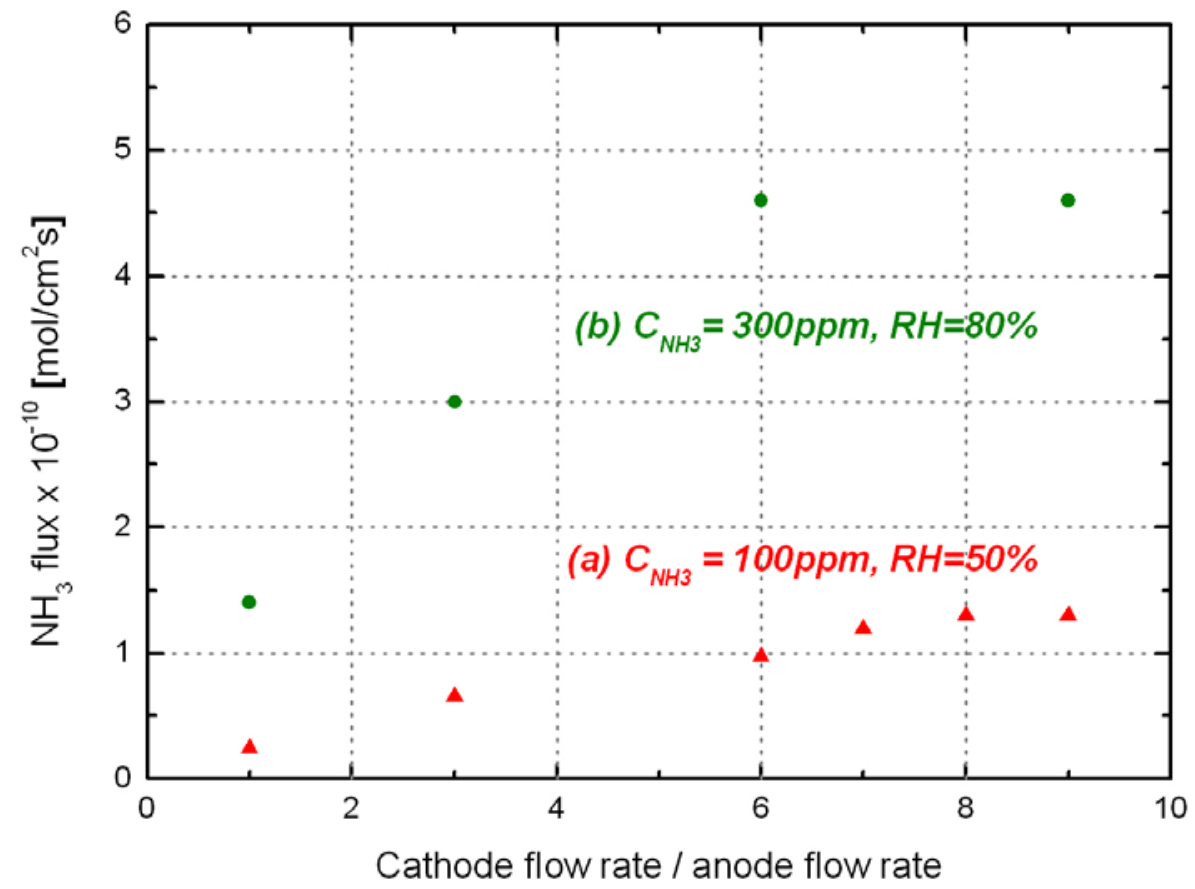

Fig. 7. The de pendence of the $\mathrm{NH}_{3}$ flux across the ME A on $\mathrm{c}$ hanges in the cathode flowrate at constant anode feed; 100 and $300 \mathrm{ppm} \mathrm{NH}_{3}$ in $\mathrm{N}_{2}$, Anode flowrate $=150 \mathrm{sccm}$, Gore $^{\mathrm{TM}}$ PRIMEA $^{\circledR} 5710$ at $\mathrm{T}_{\text {cell }}=80^{\circ} \mathrm{C}, \mathrm{RH}=50$ and $80 \%$ 


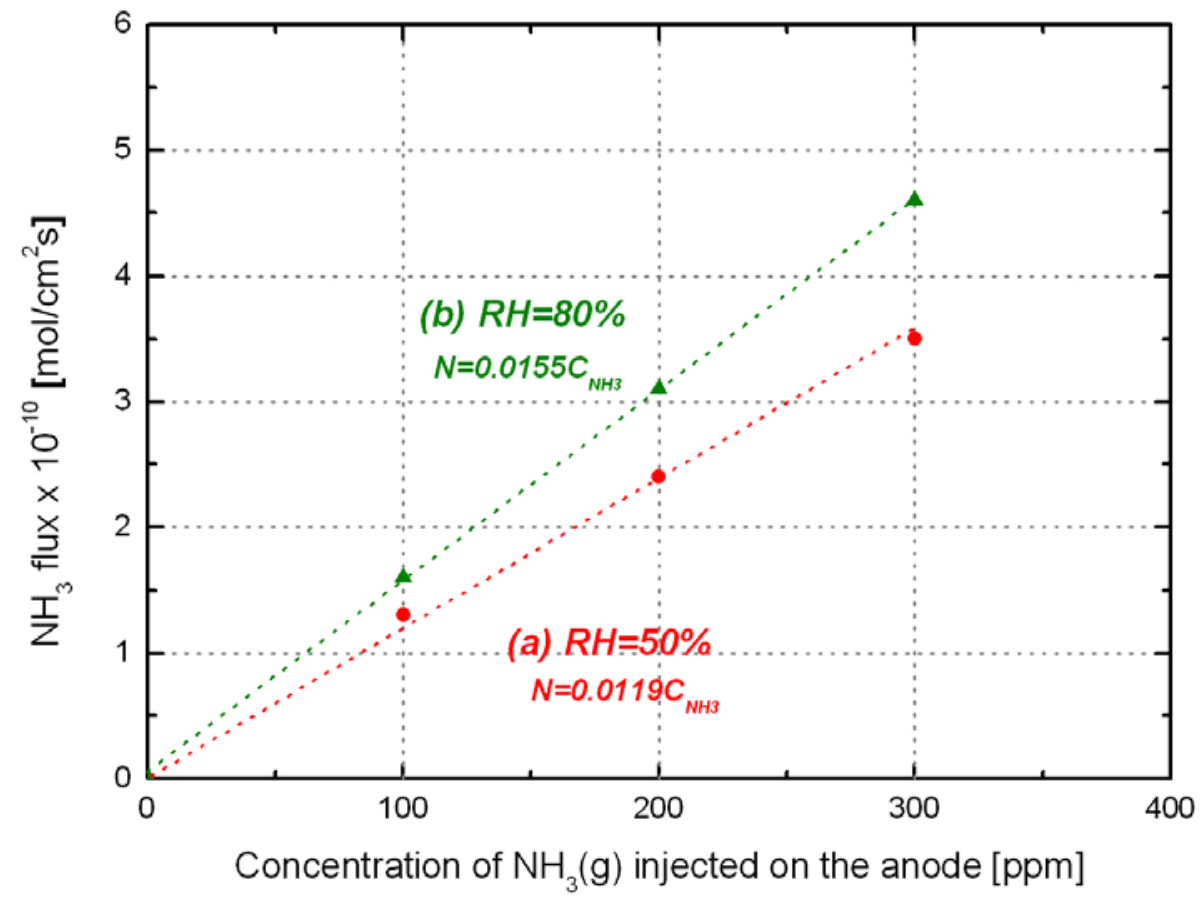

Fig. 8. Verification of diffusion-solubility mechanism at $\mathrm{OCV} ; 100$ and $300 \mathrm{ppm} \mathrm{NH}_{3}$ in $\mathrm{N}_{2}$, Flowrate $\mathrm{A} / \mathrm{C}=150 / 1200 \mathrm{sccm}$, Gore $^{\mathrm{TM}}$ PRIMEA $^{\circledR} 5710$ at $\mathrm{T}_{\text {cell }}=80^{\circ} \mathrm{C}$; (a) $\mathrm{RH}=50 \%$ (b) $\mathrm{RH}=80 \%$ 